УДК 811.111.161

DOI 10.11603/me.2414-5998.2020.2.11152

N. Ye. Koshil

ORCID https://orcid.org/0000-0003-2539-3122

ResearcherID H-6422-2017

N. V. Rybina

ORCID https://orcid.org/0000-0001-6260-9039

ResearcherID G-9745-2017

O. S. Hyryla

ORCID https://orcid.org/0000-0002-6645-4959

ResearcherID Q-7120-2017

Ternopil National Economic University

\title{
LINGUISTIC FEATURES OF THE STUDENT ABSTRACT AS A SPECIFIC PART OF THE EDUCATIONAL PROCESS
}

\author{
Н. Є. Кошіль, Н. В. Рибіна, О. С. Гирила \\ Тернопільський національний економічний університет

\section{ЛІНГВІСТИЧНІ ОСОБЛИВОСТІ СТУДЕНТСЬКОГО КОНСПЕКТУ ЯК СПЕЦИФІЧНОЇ ЧАСТИНИ НАВЧАЛЬНОГО ПРОЦЕСУ}

\begin{abstract}
The article is dedicated to the study of student writing abstract specificity by analyzing its linguistic features. The authors study the communicative and genre nature of the training abstract and propose the classification of student abstracts according to the different features. The analysis of the main types of speech genres that are inherent in students' lecture notes are carried out: informative, compelling, etiquette and evaluating. It has been conducted a survey to find out the level of students' in writing abstracts and distinguish the most popular forms of abstract's writing. The analysis of multilevel criteria has allowed the authors to propose the functionally oriented typology of student abstracts, which takes into account the outside of their design, the specifics of the informative-semantic expression and composition, as well as lexical and grammatical indicators, including syntactic and punctuation. It has also been considered the role of the author in the abstract's form as a participant of the communication, who seeks to successful communication with the lecturer. The attention is focused on structural, vocabulary and syntactic components of the abstract. The conducted research has shown that the students were not taught how to make the abstract correctly neither at school nor at the university and everybody learnt and got used to make notes by himself. It gives the authors possibility to suggest this topic to be the necessary part of the curriculum for the first-year students at the universities of the different types.
\end{abstract}

Key words: student abstract; speech genre; linguistic aspect; author; communicative goal.

Анотація. Стаття присвячена аналізу специфіки написання студентами конспекту шляхом аналізу його мовних особливостей. Автори вивчають комунікативну та жанрову природу навчального конспекту і пропонують класифікацію студентських конспектів за різними ознаками. Проведено узагальнення та аналіз основних видів мовленнєвих жанрів, притаманних лекційним записам студентів. Зокрема, виявлено переважаючу кількість інформативних конспектів. У рамках написання роботи авторами було проведено опитування з метою визначення рівня навичок та вмінь студентів у сфері створення конспектів та виявлення найпопулярніших форм його написання. Аналіз багаторівневих критеріїв дозволив авторам запропонувати функціонально орієнтовану типологію конспектів студентів, яка враховує зовнішнє їх оформлення, специфіку інформативно-семантичного вираження та складу, а також лексичні та граматичні показники, у тому числі синтаксичні характеристики і розділові знаки. У роботі також було розглянуто роль автора в імплементації форми написання конспекту як учасника спілкування, котрий прагне до успішної комунікації з лектором. Увага приділяється структурним, словниковим та синтаксичним компонентам конспектів. Проведене дослідження показало, що студентів не навчали, як правильно робити конспект ні в школі, ні в університеті, і переважаюча кількість студентів вивчала процес та способи написання конспектів самостійно. Це дало авторам можливість вважати, що ця тема $\epsilon$ необхідною частиною навчальної програми для введення в курс першого року навчання студентів в університетах різних типів.

Ключові слова: студентський конспект; мовний жанр; лінгвістичний аспект; автор; комунікативна мета.

(C) N. Ye. Koshil, N. V. Rybina, O. S. Hyryla 


\section{Materials of International Scientific and Practical Conference \\ "PROFESSIONAL AND COMMUNICATION CULTURE OF THE FUTURE DOCTOR: LINGUISTIC, PEDAGOGICAL AND PHILOSOPHICAL ASPECTS”}

Introduction. The introduction of the Bologna process into the education system of Ukraine requires significant changes in the form of education organization in higher education institutions. Nowadays, the issue of student `s individual work becomes urgent, since this type of activity is the main means of realization of mental activity and helps to increase the effectiveness of learning. The process of mastering the skills and organization of the educational activity of students involves working with textual material and knowledge of the basic principles of its comprehension. The role of the student abstract in this process is of particular importance because the student develops an appropriate way of thinking and arguing the recommended material.

The aim - to study the specifics of writing an abstract by analyzing its linguistic features.

Theoretical framework. Abstract is studied as a kind of text in various fields of knowledge, but it is thoroughly considered in linguistics, pedagogy, and pedagogical rhetoric. In the educational and methodical literature, the abstract is described as a concise writing of something [2], the methodological features of writing abstracts are analyzed and it is given an advice to students and lecturers on the optimization of text activity. Considering the abstract as a text during the lecture or the practicals, most authors gave recommendations on how to learn, how to use mental activity effectively while working, to make a summary that would be easy to read and at the same time facilitate the memorization of material; what set of practical tasks is advisable to choose to develop the skills of drafting a synopsis. At the same time, the issue regarding the communicative-genre nature of the student's educational syllabus remains unexplored, based on the ambiguity of solving the question of the primacy/secondaryity of the analyzed genre. The division of genres into primary and secondary genres, proposed by M. M. Bakhtin is not strictly functional [1]. The primary genres function in everyday communication, while the secondary genres "emerge in the context of more complex and relatively organized communication (mostly written): artistic, scientific, socio-political" [1]. Abstract as a type of written text arises in terms of educational and scientific communication, and therefore, on this basis it can be considered as a secondary genre. The primary genres are the source material for the secondary genres, which are transformed, lose their independence, become part of the whole lost genre. M. M. Bakhtin names a novel, a monograph, a business writing as an example of secondary genres [1]. As the primary genre for the educational syllabus is a lecture by the teacher, so in this aspect the abstract can be attributed to the secondary genre.

In addition, the question of the genre status of the synopsis and its characteristics remains opened. The language genre in modern linguistics is defined as a thematic, compositional and stylistic type of utterances (texts) [4]. In our opinion, there are good reasons to qualify the student's abstract as a specific language genre. However, to test this assumption, it is necessary to find out whether a student's abstract has those qualities that make it possible to consider it as a separate language genre. One of the most important features is the definition of the type of communicator by the following criteria: "type of addressee (personal / collective / mass); typical destination concept (peer / slave, female / male); address to the addressee / no appeal; addressee passive / addressee participant” [6].

The main feature of the language genre is the communicative purpose. Depending on the purposes of the statement, T. V. Shmeleva distinguishes four types of language genres: informative, imperative, etiquette (ritual) and evaluative. The communicative purpose of the informative type of language genre is the various operations with information: its presentation or request, confirmation or refutation. All student abstracts are united for the sole communicative purpose - to record the received information and to make further work with this information to be possible. Therefore, considering a synopsis on the basis of communicative purpose, it can be classified into the informative genre.

The specific feature of the student's abstract as an informative genre is that when creating a synopsis, information is transformed in the process of "privatization" of knowledge. This means that the alien information that the student includes in his abstract, listening to the lecture, at the time of fixing it is given to the author of the abstract: as a rule, it is understandable, receptive and only then reflected in the written version. Another feature of the informative abstract genre is the inclusion of evaluation elements (as a student perceives the information, qualifies it as particularly important and interesting and displays it with various means of graphic design of the abstract (for example, opposite one of the headings in the fields of the abstract puts a big exclamation mark. However, the presence of these elements does not change the overall informational orientation of the communicative 
goal, but merely specifies it. The student's abstract is to capture the information needed to work with it further and identify ways to further evaluate that information.

Another genre feature is an image of an author. The image of the author is information about him/ her as a participant of communication, who strives for successful communication. If we consider the student's abstract on this basis, we can say that the student independently, based solely on his own idea about effective communication in the educational and scientific sphere, directly chooses the personal form of the abstract (division into paragraphs, underlining any sentences, adherence to the rules of orthography). The author (student) can be diligent or nondiligent, attentive or inattentive. The student, who is the author of the abstract, can only express his/her attitude towards the lecturer only in writing form in the workbook, using the space in the fields to express his/her thoughts with different information symbols, question marks and stress. Usually, the student who is present at the lecture, wants to get information about the subject and fix it, he is interested in such a written fixation of educational material, which, in accordance with the requirements of clarity, accessibility, logic, separation of the main opinion, would allow without difficulty to restore it in memory. If the student is not interested in lecturing, he does not write at all or write some individual sentences, he can even draw in a workbook. In this case, such a record is not a complete source of information, and therefore is not a proper note. The authors of the abstract show their level of subject competence in different ways. If a student does not consider himself or herself a competent enough, he or she tries to capture as much information as possible in the hope that over time he/she will return to some unclear questions and clarify them. If the author considers himself competent enough, he writes briefly, giving space for thought in the future reading of the abstract. A student who does not completely understand the material writes everything in a row, trying to record the entire lecture automatically. Undoubtedly, an important characteristic of the image of the author is the ability to differentiate perceived information, distinguishing in it the main and secondary idea. Considering this fact, the teacher wants to look through the abstract, the author understands that the text should be written in a sufficiently legible handwriting, neat and should not contain extra records. If the author predicts further communicative behavior about the abstract - his repeated reading and receiving useful information in the future, the texts are stored for a long time, and periodically accessed. The next two symmetrical signs are related to the place of each language genre in the language communication chain [6]. Consider the factors of the past and future, taking into account the student's abstract.

Abstract is a reaction to a lecture that is considered almost simultaneous, parallel to the recording of the text. The abstract is always the answer to a previous language activity (lecture). The lecture begins first, then the note-taking begins, then the lecture and abstract are held in parallel. As the abstract is a source of information, the image of the future in this case is the intention to further reproduce and use the information. The expected effect of a student's syllabus is the following: a well-drawn abstract is an opportunity to retrieve previously recorded information, in particular, a chance to prepare effectively for the exam. If it is impossible to extract the necessary information from the recording of the lecture, the abstract does not reach its purpose and it ceases to be abstract. The most likely future language genre is a consequence of using an abstract - an oral presentation at the workshop, credit and examination.

One of the linguistic parameters of the genre is the formal organization of the linguistic genre. In the linguistic aspect, the formal organization of the genre provides for a range of lexical and grammatical possibilities [6]. Knowledge of multilevel language resources of a particular genre allows the creator of the text to choose specific means of realization of communicative design (lexical and grammatical units, syntactic constructions, punctuation marks and other means of graphic and compositional design), individuality, minimality/maximality of verbal expression. Formal and informal genres differ dramatically in terms of individuality. As a genre at the intersection of the official educational and scientific communication sphere and the informal sphere of auto communication, and where there are signs of secondaryness, a double cliches is characteristic: the linguistic cliches of the lecturer are superimposed on the standards produced by the author of the abstract. Concerning the minimum/maximum of verbal expression, the analyzed genre demonstrates a wide and multi-component scale of explicitness. The student, taking note of the lecture, is in a time-saving mode, so he is forced to resort to various abbreviations, reference signals, graphic symbols in order to capture as much information as possible in the notebook. Individual note-taking style is manifested in the gradual finding 
by the student of the optimal balance between opposing communicative properties of the genres determined in relation to each other: informational redundancy of the lecture and informational compression of the abstract.

Concerning the grammar and punctuation in the text, it should be noted that this factor is also one of the genre traits. Punctuation of non-codified texts, in particular, genre of student's abstract, has a peculiarity that requires research attention. The authors of the abstracts develop their punctuation rules and use their punctuation rules. Therefore, studying the functioning of punctuation in the student's abstract is necessary to evaluate the role of the punctuation component in the semantics and pragmatics of non-codified text. The notion of abstract as a special linguistic genre, homogeneous text material allows to characterize punctuation practice quite consistently, to reveal peculiarities of punctuation in the text, to trace dynamics of changes of punctuation norms, to formulate punctuation rules and to give them linguistic interpretation. The analysis of multilevel criteria allows us to propose the following functionally oriented typology of student abstracts, which takes into account the outside of their design, the specifics of the informative-semantic expression and composition, as well as lexical and grammatical indicators, including syntactic and punctuation.

To find out what is the most popular way of the class noting it was conducted a survey among the students of the TNEU. 125 bachelor students were proposed to answer some questions about their manner of making motes in class. First of all, it should be noted that among 125 young people 112 answered that they hadn't been previously taught how the student abstract should be written. That's why we suppose to recommend the academic authorities to introduce this topic into the curriculum for the first-year students. It would make them more confident and teach them how to manage their time and received information during their classes properly.

As a result of the survey we have also got the following classifications of the notes being used by the listeners of the higher school and the percentage of young people who use this or that form of noting during the classes.

By volume of lecture notes the summaries can be of the following types:

- full (voluminous, detailed) - $32 \%$;

- short (containing only records of the main parts) $-56 \%$;
- fragmentary records (on the last pages) - $12 \%$.

According to the degree of correspondence to the topic, the abstracts can be informative, including records only on the topic (62\%); partially evaluative, having records from the subject ( $25 \%)$, expressing the author's point of view on the presentation of the material in the lecture ( $2 \%)$, on the evaluation by the lecturer of the material (11\%), on the volume of educational material.

According to the proposals of different complexity and length the abstracts can be distinguished by writing in simple sentences (34\%); containing the complex sentences (7\%); simple and complex sentences (59\%).

According to the usage of short words:

detailed (words are written in full) $-9 \%$;

abstracts which include abbreviations, characters that are only understood by the author $-91 \%$.

According to the degree of linguistic correctness of the records:

quite literate $-16 \%$;

with many errors $-71 \%$;

with few errors $-13 \%$.

According to the terms of accuracy: neat $-38 \%$; untidy $-11 \%$; contain neat and untidy records $-51 \%$.

According to the handwriting: legible $-52 \%$; illegible $-48 \%$; large handwriting - $36 \%$; small handwriting $-64 \%$.

In general, obviously, the above classification characterizes the abstract taking into account various features, but the main emphasis was mainly on the syntactic components of the abstract. Student abstract is one of the varieties of written language genres that has stable genre characteristics.

Conclusions and Prospects for Research. To sum up, the result of the student abstract is a well-structured record, which allows the author to restore the necessary information in memory over time easily and completely. It has got different types and forms, so every student can choose any kind he needs. Unfortunately, the conducted survey has shown that the students are not taught how to make the abstract correctly neither at school nor at the university and everybody learnt and got used to make notes by himself. It gives us possibility to suggest this topic to be the necessary part of the curriculum for the first-year students at the unversities of the different types. However, this issue needs further research and analysis for being completely sure in its demand among young people. 


\section{Materials of International Scientific and Practical Conference \\ "PROFESSIONAL AND COMMUNICATION CULTURE OF THE FUTURE DOCTOR: LINGUISTIC, PEDAGOGICAL AND PHILOSOPHICAL ASPECTS”}

\section{List of literature}

1. Бахтин М. М. Проблема речевых жанров / М. М. Бахтин // Автор и герой: к философским основам гуманитарных наук / М. М. Бахтин. - СПб. : Азбука, 2000. - С. 249-299.

2. Конспект // Великий тлумачний словник суч. укр. мови. - 6-те вид. - К. ; Ірпінь : Перун, 2015.

3. Кошіль Н. Є. Лінгвістичні особливості конспекту як специфічного мовленнєвого писемного жанру / Н. Є. Кошіль, О. С. Гирила // Наукові записки Національного університету «Острозька академія». - 2015. - С. 100-102.

\section{References}

1. Bahtin, M.M. (2000). Problema rechevykh zhanrov. Avtor i geroy: $k$ filosofskim osnovam gumanitarnykh nauk [The issue of the speech genres. Author and hero: to the philosophical foundations of the humanities]. Saint-Petersburg: Azbuka [in Russian].

2. (2015). Konspekt [Notes]. Velykyi tlumachnyi slovnyk such. ukr. movy [The Great Dictionary of Modern Ukrainian Language, $6^{\text {th }}$ edition]. Kyiv; Irpin: Perun [in Ukrainian].

3. Koshil, N.Ye., \& Hyryla, O.S. (2015). Linhvistychni osoblyvosti konspektu yak spetsyfichnoho movlennievoho pysemnoho zhanru [Linguistic features of the synopsis as a specific genre of written speech]. Naukovi zapysky Natsionalnoho universytetu "Ostrozka akademiia”- Scien-
4. Мацько Л. І. Стилістика української мови : підручник / Л. І. Мацько, О. М. Сидоренко, О. М. Мацько ; за ред. Л. І. Мацько. - К. : Вища шк., 2003. - 462 с.

5. Остин Дж. Л. Слово как действие / Дж. Л. Остин // Новое в зарубежной лингвистике. - М., 2016. - Вип. 17. - С. 22-129.

6. Шмельова Т. В. Мовний жанр. Можливості опису і використання у викладанні мови / Т. В. Шмельова // Russistik = Русистика. -2010 . - № 2. - С. 20-32.

tific Notes of the National University "Ostroh Academy", 100-102 [in Ukrainian].

4. Matsko, L.I. (Ed.). (2003). Stylistyka ukrainskoi movy: Pidruchnyk [Stylistics of the Ukrainian language]. Kyiv: Vyshcha shkola [in Ukrainian].

5. Ostin, Dzh. L. (2016). Slovo kak deystviye [Word as an action]. Novoye v zarubezhnoy lingvistike - New in Foreign Linguistics. Moscow [in Russian].

6. Shmelova, T.V. (2010). Movnyi zhanr. Mozhlyvosti opysu i vykorystannia u vykladanni movy [Speech genres. Options for description and use of language teeaching]. Russistik - Rusystyka, 2, 20-32 [in Ukrainian]. 